\title{
The Role of Teaching Literature in Developing the Writing Skill of Sudanese EFL Learners: A Case Study with Basic Schools Students of Al- Gezira State
}

\author{
Sheikheldin A. A. Kheirelseed, Abdul- Gadir M. A. Adam, Amir M. Albloly \\ University of Kassala, Sudan
}

\begin{abstract}
This study was set to emphasize "the role of teaching literature in developing the writing Skills of Sudanese EFL learners at Basic Schools of AlGezira State. Due to the very significance of writing skills to the learners of EFL, the researchers tried as much to explore the effective ways of how teaching literature can improve the writing skill. The descriptive, analytical and the experimental methods were adapted to conducting the study. The pre and post-test manipulated as data collection tool to measure the differences between the students who study literature and those who do not, to find out whether literature has an effective role to play in developing writing skills or not. In addition to the "questionnaire" which was distributed among (60) Sudanese EFL teachers chosen from different Basic schools inside Al-Gezira State in order to reflect their views and attitudes towards the role played by literature in developing the writing skills of EFL learners. The results the study has come out with revealed that literature has a vital role in developing the language skills in general and writing skills in particular, school library should be positively fixed and the teachers should encourage the students to gain the furthest benefit from it, textbooks should be well designed to suit the students standard and literature should be a part of the curriculum not an optional subject.
\end{abstract}

\section{Introduction}

Literature is a word of a qualitative implication, not just a neutral term for writing in general. Without the implication and belief on the part of the author that some qualities of literature are best appreciated when it is presented in a literary history. This effort to put the most memorable English writing in an intelligible historical perspective is offered as an aid to public understanding. The reader will like literature and be curious about it. Literature as a rhetoric enjoys the human sense desire and emotion as it is used to express ideologies and messages of societies in many different ways.

The researchers think that all these definitions together give a general view of the term literature, therefore, the researcher concludes that literature promotes and sustains learning language process generally and plays a vital role in developing skills specifically. This is an ideal and perfect way to define the term "literature".

Most educational systems present common features which have a strong emphasis on cognitive learning, where results can be measured objectively; the focus is on knowledge, skills and competencies. Accordingly, competition and achievement do not produce enough preoccupation for the inner life of children. Literature holds a prominent role in children's personal development since the reader becomes emotionally attached to the story and this has positive effects not only on the personal growth but also on the whole learning process. From this point of view, the Romanian curriculum for the primary school cycle includes appropriate texts which can be used for these purposes.

\section{Objectives of the Study}

- To investigating the role that teaching literature plays in developing Sudanese EFL learners' writing skills.

- Finding out whether the absence of literature has a negative effect on developing the learners' writing skills.

- Measuring and comparing the performance of learners who study literature and those who do not.

\section{Significance of the Study}

The study conducted focuses on the role of teaching literature in developing the writing skills of Sudanese EFL learners at Basic schools, to enable learners to effectively write in the use of English language, to keep pace with worldwide development in the field of the foreign language learning and furthermore to expand learners' thinking and their command of language. Also, this study is planned to aid teachers, students of English in the pursue of appreciating English literature.

\subsection{Hypotheses and Questions of the Study}

$\mathrm{H}^{1}$ : English teachers are not well-trained to link teaching literature with writing properly. 
$\mathrm{H}^{2}$ : Regular competitions in writing through literature can improve students' writing skills.

There are two questions that have been formulated below in order to verify the hypotheses and achieving the main objectives of the study as follows:

- Why literature is not taught appropriately in most Basic schools?

- To what extent regular competitions carried in writing through literature can improve students' writing skills?

\section{Literature review}

The word literature comes from the Latin word "littera" which essentially means acquaintance with letters. Literature is generally taken to mean those of writings despite the passing of years, still, inspire admiration reflection and emotion in readers. There are many ways to define literature:

- Literature could be a sort of disciplined technique for arousing certain emotions.

Drucker [1] stated that literature is generally taken to mean those of writings which despite the passing of the years, still inspire admiration reflection and emotion in readers. Literature is a word of a qualitative implication, not just a neutral term for writing in general. Without the implications and belief on the part of the author that some qualities of literature are best appreciated when it is presented in a literary history. This effort to put the most memorable English writing in an intelligible historical perspective is offered as an aid to public understanding. The reader will like literature and be curious about it.

The quest to discover a definition for "literature" is a road that is much travelled, though the point of arrival, if ever reached, is seldom satisfactory. Most attempted definitions are broad and vague, as they inevitably change over time. In fact, the only thing that is certain about literature is that the definition will change. Concepts of what is literature change over time as well. What may be considered ordinary and not worthy of comment in a period of time, may be considered literary genius in another [3]. Most forays into the question of "what is literature" go into how literature works with the reader rather than how the author set about writing it. It is the reception rather than the writing which is the object of the enquiry. Largely, that we call "literature", is often a subjective value judgment and naturally, value judgments, like a literary taster, will change.

English literature is the study of literature written in the English Language. The writers do not necessarily have to be from England but can be from all over the world.

\subsection{Writing Skills}

Writing is a set of visible signs used to represent units of language in a systematic way with the purpose of recording messages which can be retrieved by everyone who knows the language by virtue of which its units are encoded in the writing [4].

Writing is a medium of human communication that represents language and emotion with signs and symbols.

In most languages, writing is a complement to speech or spoken language.

Writing is not a language, but a tool developed by human society.

Within a language system, writing relies on many of the same structures and speech such as vocabulary, grammar and semantics, with the added dependency of a system of signs or symbols. The result of writing is called text, and the recipient of the text is called a reader. Motivations for writing include publication, storytelling, correspondence and diary [5].

Writing is the process of using symbols (letters of the alphabet, punctuation and spaces) to communicate thoughts and ideas in a readable form.

In English, writing is usually the fourth language skill that we learn. To write clearly, it is essential to understand the basic system of a language. In English, this includes knowledge of grammar, punctuation and sentence structure. Vocabulary is also necessary as is correct spelling and formatting. [6]

\section{Methods and Design of the Study}

The researchers employed the descriptive, analytical and the experimental methods for conducting the study, and SPSS program was also used in the analysis of the obtained data.

\subsection{Subjects}

The subjects of this study would be a number of randomly selected English language teachers and their students at the state of Al-Gezira. The total number of populations of the teachers is composed of sixty (60) EFL teachers selected randomly from different Basic schools inside Al-Gezira state. The total number of the students is sixty (60) students from Grade Eight selected from different basic 
schools in Al-Gezira state; they are nearly of the same age.

\subsection{Instruments}

The two instruments were manipulated in collecting the data of this study are:

- Questionnaires were distributed to EFL Basic schools teachers from different schools in AlGezira state.

- A T-test was applied to the Grade Eight students from different Basic schools in Al-Gezira state too.

\subsection{Procedures}

To seek for satisfying results, the researchers subjected the students to the test and distributed the questionnaire among the teachers. The researchers tested a group of (thirty) students who do not study literature in their English lessons (Group A) and group (B) of (thirty) those who study literature in their English lessons so as to find out how literature has a role to play in developing writing skills. The two groups of students sat for the pre-test at the same time as they did when they sit for the post-test. As to the questionnaire, it composed of twenty items emphasize the teachers' perceptions towards the role that literature can play in developing the writing skills of EFL learners. The researchers considered that the questionnaire is an appropriate tool used for the data collection as it helped the researchers obtained the required data that led to reliable findings at the end of the study. The questionnaire was designed in such organized way to attain the purposes it was intended to achieve. It was constructed and distributed to sixty teachers who teach English as a foreign language (EFL). Each of them responded according to his/her point of view by putting $(\sqrt{ })$ on the alternative that expresses his/her point of view. Finally, the researchers computerized the data adopting the Statistical Packages for Social Science (SPSS) in the analysis of the results obtained by both the test and the questionnaire.

\subsection{Validity and reliability of the Questionnaire}

In constructing the teachers' questionnaire, the researchers tried to ensure that the items are related to the objectives of the study. The questionnaire items were also supported by the available and relevant literature. Additionally, the reconstructed questionnaire was given to some colleagues and experts in the fields of Teaching English and literature who have done a critical assessment to validate the instrument. It was after their criticisms were taken care of that, the reconstructed questionnaire was passed to have a face and content validity. The teachers' questionnaire was administered to ten teachers other than the sample. Some of the teachers who participated in the pilot study were not involved in the formal questionnaire of the study. The reliability coefficient of 0.78 was established for the instrument. According to Carrol [7], the reliability coefficient to be found is above 0.77 , it is said that there is a high positive reliability. Therefore, these data gathering instruments proved to be stable, dependable and highly reliable.

\subsection{Validity and reliability of the Test}

In order to assure the validity of the instrument, it was submitted to a group of colleagues and specialists in the field of testing and measurement. The judges were asked to base their judgment on the following criteria:

- Suitability of each item to the related area,

- Clarity and accuracy of the language.

The judges' suggested amendments' changes, and deletion. Over $75 \%$ of their suggestions have been taken into consideration. The test was tried on fifteen students other than the sampled students. Then, two weeks later the test was administered to the same students. Both administrations were scored accordingly. A reliability coefficient of 0.78 was established. According to the statistical equation, such a figure for reliability is considered convincing enough.

\section{Data analysis and Discussion of Results}

Approximately, most of the teachers' responses expressed positive attitudes towards English literature and its vital role in developing writing skills.

Table 1. Frequency distribution of teachers according to academic qualification

\begin{tabular}{|c|c|c|}
\hline Qualification & Frequency & \% \\
\hline Diploma & 16 & 26.7 \\
\hline Bachelor & 30 & 50.0 \\
\hline Master & 14 & 23.3 \\
\hline Total & 60 & $100 \%$ \\
\hline
\end{tabular}

The academic qualifications of teachers understudy as shown in the Table 1 and Figure 1 above. Where 26.70 of them were diploma holders, $50 \%$ were bachelor holders and $23.3 \%$ teachers held the master's degree. 
Table 2. Frequency distribution of teachers according to years of experience

\begin{tabular}{|l|c|c|}
\hline Answer & Frequency & \% \\
\hline Agree & 46 & 76.7 \\
\hline Neutral & 4 & 6.7 \\
\hline Disagree & 10 & 16.7 \\
\hline Total & 60 & $100 \%$ \\
\hline
\end{tabular}

The Frequency distribution of teachers according to their years of experience was presented in Table 2 above which reflected that $43.3 \%$ of them their experience below 5 years, 26.\% between 6-10 years, $20 \%$ between $11-15$ years and $10 \%$ were above 15 years.

Table 3. Literature should be a compulsory part of the English curriculum.

\begin{tabular}{|l|c|c|}
\hline Answer & Frequency & \% \\
\hline Agree & 46 & 76.7 \\
\hline Neutral & 4 & 6.7 \\
\hline Disagree & 10 & 16.7 \\
\hline Total & 60 & $100 \%$ \\
\hline
\end{tabular}

The literature books should be a compulsory part of the English curriculum. The above Table 3 indicated that most of the teachers $76.7 \%$ agreed that literature should be a compulsory part of the curriculum, $16.7 \%$ disagreed and $6.7 \%$ were neutral.

Table 4. Literature should be an optional subject

\begin{tabular}{|l|c|c|}
\hline Answer & Frequency & $\boldsymbol{\%}$ \\
\hline Agree & 6 & 10.0 \\
\hline Neutral & 2 & 3.3 \\
\hline Disagree & 52 & 86.7 \\
\hline Total & 60 & $100 \%$ \\
\hline
\end{tabular}

The majority $86.7 \%$ of the teachers in the Table 4 above disagreed that literature should be an optional subject, while $10 \%$ of them agreed and $3.3 \%$ were neutral.

Table 5. Textbooks and literature books

\begin{tabular}{|l|c|c|}
\hline Answer & Frequency & \% \\
\hline Agree & 52 & 86.7 \\
\hline Neutral & 2 & 3.3 \\
\hline Disagree & 6 & 10.0 \\
\hline Total & 60 & $100 \%$ \\
\hline
\end{tabular}

The textbooks and literature books are not welldesigned to suit the students' needs of writing skills. As shown in Table 5, most of the investigated views of teachers $86.7 \%$ agreed that textbooks are not welldesigned, $10 \%$ disagreed and the rest $3.3 \%$ were neutral.

Most of the teachers according to the Table 6 below $93.3 \%$ agreed that English library is very important for basic school students while $3.3 \%$ disagreed and $3.3 \%$ were neutral.
Table 6. English library is important for developing basic school students' writing skills.

\begin{tabular}{|l|c|c|}
\hline Answer & Frequency & \% \\
\hline Agree & 56 & 93.3 \\
\hline Neutral & 2 & 3.3 \\
\hline Disagree & 2 & 3.3 \\
\hline Total & 60 & $100 \%$ \\
\hline
\end{tabular}

Table 7. English teachers are not well-trained to link teaching literature with writing properly.

\begin{tabular}{|l|c|c|}
\hline Answer & Frequency & \% \\
\hline Agree & 48 & 80.0 \\
\hline Neutral & 10 & 16.7 \\
\hline Disagree & 2 & 3.3 \\
\hline Total & 60 & $100 \%$ \\
\hline
\end{tabular}

It is noticeable that in the Table 7 above that most of the teachers $80 \%$ agreed that English teachers are not well-trained to teach literature in an interesting way, $3.3 \%$ disagreed and $16.7 \%$ of them were neutral.

Table 8. Regular competitions in English writing improve students' writing skills.

\begin{tabular}{|l|c|c|}
\hline Answer & Frequency & \% \\
\hline Agree & 48 & 80.0 \\
\hline Neutral & 4 & 6.7 \\
\hline Disagree & 8 & 13.3 \\
\hline Total & 60 & $100 \%$ \\
\hline
\end{tabular}

As manifested in the Table 8, that $80 \%$ of investigated views of teachers agreed that regular competitions in English writing improve students' writing skills, $13.3 \%$ disagreed and the rest $6.7 \%$ were neutral.

Table 9. Independent Sample T-test Between Pre and Post test

\begin{tabular}{|c|c|c|c|c|c|}
\hline Test & Means & STD & $\begin{array}{c}\text { T-test } \\
\text { Value }\end{array}$ & D.f & Sig \\
\hline Pre test & 4.30 & 2.23 & 4.85 & 53 & 0.00 \\
\hline Post-test & 7.02 & 2.04 & & & \\
\hline
\end{tabular}

The result according to Table 9 shows that there is a significant difference between the means of the students' performance in the pretest and posttest. It is noticed that the expected means in the posttest is greater than the expected means in the pretest which reflects a significant difference between the students' performance in both tests where the sig value 0.00 is less than 0.05 .

In the light of the above manifestation of discussion and results, it is noticed that all the abovediscussed statements and students performance in the test, is in support of the hypotheses posed by the study which calls for the positive effect and role played by literature in developing the writing skills of EFL Basic schools' students at Al-Gezira State. 


\section{Conclusion}

Based on the analysis and description of the procedures that are carried out by the research, test and the questionnaire, the study offered the following findings as a result of the student's scores as reflected in the pre and post-test; these findings can be outlined as follows:

- Literature should be a compulsory part of the English curriculum,

- Literature should be an optional subject,

- Textbooks and literature books are not welldesigned to suit the students' needs of writing skills,

- English library is important for developing basic school students' writing skills,

- English teachers should be well-trained to teach literature properly and regular competitions in English writing can improve students' writing skills.

Furthermore, as literature does have an effective role to play in developing writing skills from one hand, it can enhance the learners' command of language on the other hand. The finding of this study suggests that literature should be integrated into the spine series course as a main as other topics and should be taught at all levels at Basic school stage.

\section{References}

[1] Drucker, H., (2015). The Importance of Teaching Literature. Laurie Patsalides.

[2] Hamp-Lyons, L. and Heasley, B., (1987). Study writing. Cambridge. Cambridge University Press.

[3] Hillway, T., (1969). Handbook of Educational Research. Dallas U.S.A. http://Modena. Integrate.ca/perso nal/gslj/puncex answer (Access Date: 11 May, 2017).

[4] Lee. J., (2015). Primary School Composition Writing, Writingsamurai.com. Singapore.

[5] Lee. J., (2016). How to write a composition, For Primary School Students, Writingsamurai.com. Singapore.

[6] Robbery, C. L. et al., Handbook of Basic Writing Skills, New York Harcourt Brace Jovanovich, INC. 1978.

[7] Carroll, B.J., Hall, P.J., (1985). Make Your Own Language Tests: A Practical Guide to Writing Language Performance Tests. Pergamon, Oxford. 